\title{
Modelling the Respiration Rate of Fresh-Cut Pear (Pyrus communis L.) Packaged in Modified Atmosphere
}

\author{
Ram Prakash Kumar* and T.K. Goswami \\ Department of Agriculture and Food Engineering, Indian Institute of Technology, \\ Kharagpur, India \\ *Corresponding author
}

\section{A B S T R A C T}

Keywords

Modified atmosphere packaging,

Chemical treatment, Polypropylene,

Respiration,

Enzyme kinetics

Article Info

Accepted:

07 March 2019

Available Online:

10 April 2019

\begin{abstract}
Respiration rate is the important factor involved in creating a modified atmosphere inside a package that will extend the shelf life of fresh fruits and vegetables. Thus, modelling respiration rate of the selected produce is crucial to develop a modified atmosphere packaging (MAP) system. In this study, MAP has been combined with $1 \%$ Calcium chloride and $1 \%$ citric acid solution. Respiration rates of fresh-cut pear packaged in polypropylene pouches at $8{ }^{\circ} \mathrm{C}$. A mathematical model describing the dynamics of $\mathrm{O}_{2}$ and $\mathrm{CO}_{2}$ concentrations inside the MAP package of fresh-cut pear was formulated. It was found that the Michaelis-Menten equation with uncompetitive inhibition kinetic fitted best with the experimental results. The results of the model agreed well with the experimental results with the values of the correlation coefficient, $r^{2}>0.90$. The model could be used to develop a modified atmosphere packaging (MAP) for fresh-cut pear.
\end{abstract}

\section{Introduction}

Pear (Pyrus communis L.) is a gently sweet juicy fruit with glitter texture and delicious taste. Pears are a rich source of vitamin C, quercetin and copper, which protect cells from damage by free radicals. Pears are high in dietary fibre, containing $6 \mathrm{~g}$ per serving (Reiland and Slavin, 2015). The fruit contains a high amount of pectin, which lowers down the levels of low-density lipoprotein (LDL) and triglycerides thereby reducing the risk of high cholesterol (Velmurugan and Bhargava, 2013). It possesses multiple medicinal properties such as anti-inflammatory, sedative, anti-pyretic, anti-oxidants, hypolipidemic, hypoglycaemic, anti-ageing, anti-tussive, anti-diarrheal, and hepatoprotective (Parle and Arzoo, 2016).

Respiration of fruits and vegetables is the biochemical process in which sugars and oxygen are converted into carbon dioxide, water, and heat. Controlling respiration is 
essential to store produce for a long time. By storing a commodity at low temperature, respiration is reduced and senescence is delayed, thus extending storage life (Halachmy and Mannheim, 1991). Proper control of the oxygen and carbon dioxide concentrations surrounding a commodity is also effective in reducing the rate of respiration. Modified atmosphere packaging (MAP) is a technique used for prolonging the shelf-life of fresh or processed foods by modifying the air surrounding the food in the package to a different composition. Inside packages, $\mathrm{O}_{2}$ concentration is reduced while $\mathrm{CO}_{2}$ concentration is increased, causing a reduction in product's respiration rate and a consequent slowing down of senescence and decay phenomena (Das et al., 2006). However, modified atmosphere packaging (MAP) alone does not completely control the post-cutting enzymatic browning of fresh-cut fruits (Gorny et al., 2002). The greatest hurdles to the commercial marketing of freshcut fruit products are limited shelf-life due to the browning of cut surface and rapid loss of firmness. Cut surface browning in sliced is caused by the action of polyphenol oxidase (PPO) on phenolic compounds released during the process of cutting (Amiot et al., 1995). Fruit tissue softening during ripening and senescence is a consequence of alterations in cell wall metabolism triggered by ethylene. There are numerous chemical and physical preservation strategies that can be used to reduce enzymatic browning and fruit tissue softening after cutting. A great number of studies have been conducted to avoid browning surfaces on fresh-cut fruits using selected agents such as ascorbic acid, 4hexylresorcinol, cysteine, N-acetylcysteine and sodium erythorbate (Arias et al., 2008; Dong et al., 2000; Oms-Oliu et al., 2006; Sapers and Miller, 1998; Soliva-Fortuny et al., 2002). Another concern related to the extension of shelf life for fresh-cut fruit is softening, which is primarily due to enzymatic degradation of the cell wall Calcium salts, and particularly calcium chloride and lactate, are generally used in combination with browning inhibitors as firmness-maintaining agents in a wide range of cultivars of fresh-cut fruit and vegetables (Alandes et al., 2006).

Combinations of modified atmosphere packaging (MAP) and chemical treatment have been successfully studied to increase the shelf-life of various fruit such as strawberry (Aguayo et al., 2006), litchi (Sivakumar and Korsten, 2006), banana (Vilas- Boas and Kader, 2006), apple (Rocculi et al., 2004) and fresh-cut pear (Sapers and Miller, 1998).

The objectives of this study were developing a suitable model for determining the respiration rate of fresh-cut pear and to find out the combined effect of chemical treatment with MAP on the respiration rate of freshly cut pear.

\section{Materials and Methods}

\section{Sample preparation}

The fresh William Bartlett variety pears were purchased from the local fruit market in Kharagpur. The pears were stored in the refrigerator for 3 hours at $0 \mathrm{C}$ to assure its freshness. The selected quantity of pears was washed by running tap water, dried by cotton and peeled by peeler manually. Then each pear was cut into 7-8 wedges using a sharp knife. Then the cut pears were dipped in water to avoid frequent surface browning by contact of air. After that, each wedge of pear dried by tissue paper dipped in a chemical solution $(1 \%$ citric acid $+1 \%$ calcium chloride which was previously prepared) for 5 minutes. Then samples were removed from the container and put in a glass plate. Pear slices were subjected to four different treatments: (1) Map + Treated $-\left(1 \%\right.$ citric acid $\left.+1 \% \mathrm{CaCl}_{2}\right)$ and 
stored in MAP at $8^{\circ} \mathrm{C}$, (2) Treated $-(1 \%$ citric acid $+1 \% \mathrm{CaCl}_{2}$ ) and stored at room temperature and regular atmosphere, (3) MAP + Untreated -No chemical treatment and stored in MAP at $8^{\circ} \mathrm{C}$, (4) Untreated - No chemical treatment and stored at room temperature and regular atmosphere. The samples of all groups were replicated three times and stored for 8 days.

\section{Packaging material}

Pear wedges were packaged in polypropylene (PP) pouches of size $12 \times 20 \mathrm{~cm}$ from inside and $0.025 \mathrm{~mm}$ thickness (Nath et al., 2012). The gas permeability of packaging material was $2660 \mathrm{cc} \mu \mathrm{m} \mathrm{m}^{-2} \mathrm{~h}^{-1}$ for $\mathrm{O}_{2}$ and $14958 \mathrm{cc} \mu \mathrm{m}$ $\mathrm{m}^{-2} \mathrm{~h}^{-1}$ for $\mathrm{CO}_{2}$ at 1 atm.

\section{Respiration data}

The respiration data of samples in MAP were estimated by sealed chamber technique (Forcier et al., 1987). A special type of container (respirometer) made out of acrylic sheet was fabricated for measurement of the rate of $\mathrm{O}_{2}$ utilized and $\mathrm{CO}_{2}$ produced (Plate $1)$. The dimensions and volume of the container were $23.5 \times 18 \times 13.5 \mathrm{~cm}$, and 5600 $\mathrm{ml}$, respectively. The container was filled one with treated and another one with untreated pear such that the free volume was minimum. Then the container was sealed and kept in a refrigeration chamber at a pre-set temperature $\left(8^{\circ} \mathrm{C}\right)$. The concentrations of $\mathrm{O}_{2}$ and $\mathrm{CO}_{2}$ were measured using a gas analyzer (PBI; Dansensor, Ringsted, Denmark) after every 8 hours. The procedure was repeated three times for both treated and untreated pear. The concentrations of $\mathrm{O}_{2}$ and $\mathrm{CO}_{2}$ were recorded till the $\mathrm{CO}_{2}$ concentration reaches $18 \%$.

\section{Modelling of respiration rate}

Respiration rates can be measured by observing the concentration of $\mathrm{O}_{2}$ consumption or $\mathrm{CO}_{2}$ production per unit weight of the fruit per unit time. Letthe head space inside the container was $\mathrm{V}(\mathrm{mL})$ and the weight of fruit kept in the container was $\mathrm{W}$ $(\mathrm{kg})$. At time $\theta_{\mathrm{i}}$, the concentrations of $\mathrm{O}_{2}$ and $\mathrm{CO}_{2}$ were $\mathrm{y}_{\mathrm{i}}$ and $\mathrm{z}_{\mathrm{i}}$, respectively andafter time $\theta_{\mathrm{i}+1}$, the concentrations of $\mathrm{O}_{2}$ and $\mathrm{CO}_{2}$ changed to $\mathrm{y}_{\mathrm{i}+1}$ and $\mathrm{z}_{\mathrm{i}+1}$, respectively. Therefore, the rates of $\mathrm{O}_{2}$ consumption, $\mathrm{R}_{\mathrm{y}}$ $\left(\mathrm{mL} \mathrm{kg} \mathrm{kh}^{-1}\right)$ and of $\mathrm{CO}_{2}$ production, $\mathrm{R}_{\mathrm{z}}(\mathrm{mL}$ $\mathrm{kg}^{-1} \mathrm{~h}^{-1}$ ) at a given temperature were calculated using the following Equations (1) and (2) as given by Kays (1991):

$$
\begin{aligned}
& R_{y}=\frac{v}{w}\left(\frac{y_{i}-y_{i+1}}{\theta_{i+1}-\theta_{i}}\right)(1) \\
& R_{z}=\frac{v}{W}\left(\frac{z_{i+1}-z_{i}}{\theta_{i+1}-\theta_{i}}\right)(2)
\end{aligned}
$$

The experimental respiration rates for $\mathrm{O}_{2}$ consumption and $\mathrm{CO}_{2}$ were calculated by putting the respiration data obtained from respirometer in Equations (1) and (2).

When the variation of $\mathrm{y}$ and $\mathrm{z}$ with $\theta$ is expressed by a continuous functional relationship, the Equations (1) and (2) can be expressed as

$$
R_{Y}=\frac{\mathrm{V}}{\mathrm{W}}\left(-\frac{\mathrm{dy}}{\mathrm{d \theta}}\right)(3)
$$

$\mathrm{R}_{\mathrm{z}}=\frac{\mathrm{v}}{\mathrm{w}}\left(-\frac{\mathrm{dz}}{\mathrm{d \theta}}\right)$ (4) where dy and $\mathrm{dz}$, respectively are the concentration differences of $\mathrm{O}_{2}$ and $\mathrm{CO}_{2}$ within the time difference between two gas measurements $\mathrm{d} \theta$.

It was assumed that the respiration rate reached a stable condition when Equation (1) was verified for:

$\mathrm{R}_{\mathrm{y}}(\theta)-\mathrm{R}_{\mathrm{y}}(\theta-\mathrm{d} \theta) \leq \pm 0.05(5)$

The experiment was performed at a given temperature withthreereplications. 
Inside a hermetically sealed container, the variation of $\mathrm{y}$ and $\mathrm{z}$ as a function of $\theta$ was observed by Hagger et al., (1992) as per the following relationships:

$y=0.21-\left(\frac{\theta}{a_{y} \theta+b_{y}}\right)$

$\mathrm{z}=\left(\frac{\theta}{\mathrm{a}_{\mathrm{z}} \theta+\mathrm{b}_{\mathrm{z}}}\right)(7)$

where 0.21 is the initial value in a fraction of $\mathrm{O}_{2}$ in atmospheric air; $\mathrm{a}_{\mathrm{y}}, \mathrm{b}_{\mathrm{y}} \mathrm{a}_{\mathrm{z}}$ and $\mathrm{b}_{\mathrm{z}}$ are constants and $\theta$ is the storage time in h. After finding $\mathrm{dy} / \mathrm{d} \theta$ and $\mathrm{dz} / \mathrm{d} \theta$ from Equations (6) and (7) and putting them into Equations (3) and (4) we get,

$R_{y}=\frac{v}{w}\left(\frac{b_{y}}{\left(a_{y} \theta+b_{y}\right)^{2}}\right)$

$\mathrm{R}_{\mathrm{z}}=\frac{\mathrm{V}}{\mathrm{W}}\left(\frac{\mathrm{b}_{\mathrm{z}}}{\left(\mathrm{a}_{\mathrm{z}} \theta+\mathrm{b}_{\mathrm{z}}\right)^{\mathrm{z}}}\right)$

Using Equations (8) and (9) the values of $R_{y}$ and $R_{z}$ at different values of $\theta$ were obtained from the data available for pear kept inside hermetically sealed container. At different values of $\theta$, values of $y, z, R y$ and $R z$ were computed from Equations (6), (7), (8) and (9), respectively. The values of $R_{y}$ and $R_{z}$ were then related to the values of $\mathrm{y}$ and $\mathrm{z}$ by using regression equations.

Considering that $\mathrm{CO}_{2}$ acts as a respiration inhibitor, the effect of $\mathrm{CO}_{2}$ on the product respiration can be described by the uncompetitive inhibition (McLaughlin and O'Beirne, 1999). The maximum respiration rate is not much influenced at high $\mathrm{CO}_{2}$ concentration. At high levels of $\mathrm{CO}_{2}$ concentration (17-18\%), however, the respiration mechanism changes from aerobic to the anaerobic pathway (Mahajan, 2001). Hence Michaelis-Menten enzyme kinetics equation with uncompetitive inhibition (Lee et al., 1991) was used to develop a modelfor predicting the respiration rate of fresh cut pear. Equations (10) and (11) express the uncompetitive inhibition mechanisms for the respiration process in terms of $\mathrm{O}_{2}$ consumption and $\mathrm{CO}_{2}$ production rate, respectively. The model has three parameters viz., $\mathrm{R}_{\mathrm{m}}, \mathrm{K}_{\mathrm{m}}$, and $\mathrm{K}_{\mathrm{i}}$ for both $\mathrm{O}_{2}$ consumption and $\mathrm{CO}_{2}$ production.

$$
\begin{aligned}
& \mathrm{R}_{\mathrm{y}}=\frac{\mathrm{R}_{\mathrm{my}} \mathrm{y}}{\mathrm{K}_{\mathrm{my}}+\left(1+\frac{\mathrm{z}}{\mathrm{K}_{\mathrm{iy}}}\right) \mathrm{y}}(10) \\
& \mathrm{R}_{\mathrm{z}}=\frac{\mathrm{R}_{\mathrm{mz}} \mathrm{y}}{\mathrm{K}_{\mathrm{mz}}+\left(1+\frac{\mathrm{z}}{\mathrm{K}_{\mathrm{iz}}}\right) \mathrm{y}}(11)
\end{aligned}
$$

Where $\mathrm{R}_{\mathrm{m}}$ denotes the maximum rates $\left(\mathrm{mLkg}^{-1} \mathrm{~h}^{-1}\right), \quad \mathrm{K}_{\mathrm{m}}$ denotes the MichaelisMenten constant and $\mathrm{K}_{\mathrm{i}}$ denotes the inhibition constant. The model parameters were determined using the experimental respiration data using MS-EXCEL software.

\section{Variation of $\mathrm{O}_{2}$ and $\mathrm{CO}_{2}$ concentration inside modified atmosphere package}

Let the concentrations $(\mathrm{mL})$ of $\mathrm{O}_{2}$ and $\mathrm{CO}_{2}$ inside the package arey and $\mathrm{z}$, respectively. Similarly, $\mathrm{y}_{\mathrm{a}}$ and $\mathrm{z}_{\mathrm{a}}$ are the concentrations $(\mathrm{mL})$ of $\mathrm{O}_{2}$ and $\mathrm{CO}_{2}$ in atmospheric air, respectively. For the transfer of oxygen from atmospheric air through packaging material into the package space, following generalized equation was applied:

The rate of $\mathrm{O}_{2}$ entry into package space - Rate of $\mathrm{O}_{2}$ accumulation $=$ Rate of $\mathrm{O}_{2}$ accumulation inside package space

That is, $A_{P} k_{y}\left(y_{a}-y\right)-W_{P} \times R_{y}=V_{e} \times\left(\frac{d y}{d \theta}\right)$ (12) or $\left(\frac{d y}{d \theta}\right)=-\left(\frac{w_{p}}{v_{e}}\right) R_{y}+\left(\frac{A_{p} k_{y}}{v_{e}}\right)\left(y_{a}-y\right)(13)$

where $\frac{d y}{d \theta}$ is the rate of change of $\mathrm{O}_{2}$ concentration within the package at $\theta$ storagetime, $W_{p}(\mathrm{~kg})$ is the weight of fruit stored inside the packaging material, $\mathrm{V}_{\mathrm{e}}$ is the 
headspace inside the packaging material $(\mathrm{mL}), \mathrm{R}_{\mathrm{y}}\left(\mathrm{mL} \mathrm{kg}^{-1} \mathrm{~h}^{-1}\right)$ is the respiration rate of fruit for $\mathrm{O}_{2}, \mathrm{~A}_{\mathrm{p}}\left(\mathrm{m}^{2}\right)$ is the surface area of packaging material through which $\mathrm{O}_{2}$ and $\mathrm{CO}_{2}$ permeates, $\mathrm{k}_{\mathrm{y}}\left[\mathrm{mLh}^{-1} \mathrm{~m}^{-2}\right.$ (concentration difference of $\mathrm{O}_{2}$ infraction $)^{-1}$ ] is the $\mathrm{O}_{2}$ permeability of packaging material and $t$ is the thickness of the packaging material. Similarly, the transfer rate for $\mathrm{CO}_{2}$ from inside to outside of packaging material can be written as:

The rate of $\mathrm{CO}_{2}$ generated by fruit - Rate of $\mathrm{CO}_{2}$ leaving out of package space by fruit = Rate of accumulation $\mathrm{CO}_{2}$ inside package space.

That is,

$\mathrm{W}_{\mathrm{p}} \times \mathrm{R}_{\mathrm{z}}-\mathrm{A}_{\mathrm{p}} \mathrm{k}_{\mathrm{z}}\left(\mathrm{z}_{\mathrm{a}}-\mathrm{z}\right)=\mathrm{V}_{\mathrm{e}}\left(\frac{\mathrm{dz}}{\mathrm{d \theta}}\right)(14)$

or $\left(\frac{d z}{d \theta}\right)=\left(\frac{W_{p}}{V_{e}}\right) R_{z}-\left(\frac{A_{p k_{z}}}{V_{e}}\right)\left(\mathrm{z}_{\mathrm{a}}-\mathrm{Z}\right)(15)$

where, $\frac{\mathrm{dz}}{\mathrm{d} \theta}$ is the rate of change of $\mathrm{CO}_{2}$ concentration within the package at $\theta$ storagetime, $\mathrm{R}_{\mathrm{z}}\left(\mathrm{mL} \mathrm{kg}^{-1} \mathrm{~h}^{-1}\right)$ is the respiration rate of fruit for $\mathrm{CO}_{2}, \mathrm{~A}_{\mathrm{p}}\left(\mathrm{m}^{2}\right)$ is the surface area of the packaging material through which $\mathrm{CO}_{2}$ permeation takes place.

$\mathrm{K}_{\mathrm{z}}\left(\mathrm{mLh}^{-1} \mathrm{~m}^{-2}\right.$ (concentration difference of $\mathrm{CO}_{2}$ infraction $)^{-1}$ ) is the $\mathrm{CO}_{2}$ permeability of packaging material and using regression coefficient, simultaneous solution of Equations (13) and (15) by numerical means the variation of oxygen concentration $y$ and carbon dioxide concentration zinside the package with a time of storage $\theta$ were calculated.

\section{Results and Discussion}

\section{Respiration rate}

The respiration data obtained from closed system respirometer are shown in Figure 1.
The respiration rates of treated and untreated fresh-cut pear are shown in Table 1. It was found that the decrease in concentration of $\mathrm{O}_{2}$ was almost proportional to the increase in $\mathrm{CO}_{2}$ concentration with storage period. Similar results were reported by Mangaraj and Goswami (2011) for guava.

\section{Modelling of respiration rate}

A model based on principles of enzyme kinetics and a regression model was developed to predict the respiration rate of fresh-cut pear at any combination of $\mathrm{O}_{2}$ and $\mathrm{CO}_{2}$ concentrations.

\section{Prediction of respiration rate based on} experimental data using regression analysis

Instantaneous $\mathrm{O}_{2}$ consumption and $\mathrm{CO}_{2}$ production rates were obtained by plotting gas concentrations versus time and measuring the slopes from linear regression line and substituting the values of $(\mathrm{dy} / \mathrm{d} \theta)$ and $(\mathrm{dz} / \mathrm{d} \theta)$ in Equations (3) and (4). Regression function is often used to fit the data of gas concentration versus time and the respiration rate at the given time is determined from the first derivative of the regression function (Kang and Lee, 1998). By using the generated respiration data, a non-linear regression analysis was done to fit $\mathrm{O}_{2}$ and $\mathrm{CO}_{2}$ concentrations at different storage times.

The regression coefficient $a_{y}, b_{y}$ and $a_{z}, b_{z}$ of equations (6) and (7) and correlation coefficients $\left(\mathrm{r}^{2}\right)$ of both the sample are shown in Table 2. Respiration rate was calculated using equations (8) and (9).

The respiration rate as predicted by equations (8) and (9) was found to be decreased with the time due to depletion of $\mathrm{O}_{2}$ and accumulation of $\mathrm{CO}_{2}$ inside respirometer in both conditions. Similar observation was reported by Mangaraj et al., (2014) forguava. 


\section{Verification of the regression model}

The respiration rates of fresh-cut pear predicted through regression model shown in
Equations (8) and (9) were verified with experimental respiration rates calculated using Equations (1) and (2).

Table.1 $\mathrm{O}_{2}$ consumption rate (Ry), $\mathrm{CO} 2$ production rate $(\mathrm{RZ})$ and respiratory quotient

\begin{tabular}{|l|l|l|l|}
\hline Sample & $\mathbf{R}_{\mathbf{y}}\left(\mathbf{m L ~ k g} \mathbf{~ g}^{-\mathbf{1}} \mathbf{h}^{-\mathbf{1}}\right)$ & $\mathbf{R}_{\mathbf{z}}\left(\mathbf{m L ~ k} \mathbf{~ g}^{-\mathbf{1}} \mathbf{h}^{-\mathbf{1}}\right)$ & Respiratory Quotient $\left(\mathbf{R}_{\mathbf{z}} / \mathbf{R}_{\mathbf{y}}\right)$ \\
\hline Treated pear & 7.844 & 6.97 & 0.89 \\
\hline Untreated pear & 8.78 & 7.90 & 0.90 \\
\hline
\end{tabular}

Table.2 Regression coefficients for $\mathrm{O} 2$ consumption and $\mathrm{CO} 2$ production

\begin{tabular}{|l|l|l|l|l|l|l|}
\hline \multirow{2}{*}{ Sample } & \multicolumn{2}{|l|}{$\begin{array}{l}\text { Regression coefficients } \\
\text { For } \mathbf{O}_{2} \text { consumption }\end{array}$} & \multirow{2}{*}{$\begin{array}{l}\text { Regression coefficients } \\
\text { For } \mathbf{C O}_{2} \text { production }\end{array}$} & \multirow{2}{*}{$\mathbf{r}^{2}$} \\
\cline { 2 - 3 } & $\mathrm{a}_{\mathrm{y}}$ & $\mathrm{b}_{\mathrm{y}}$ & & $\mathrm{a}_{\mathrm{z}}$ & $\mathrm{b}_{\mathrm{z}}$ & \\
\hline Treated pear & 6.922 & 624.075 & 0.9993 & 7.0012 & 811.967 & 0.9997 \\
\hline Untreated pear & 6.658 & 486.126 & 0.9988 & 5.5014 & 698.839 & 0.9998 \\
\hline
\end{tabular}

Table.3 Model parameters of enzyme kinetics for treated and untreated fresh-cut pear

\begin{tabular}{|l|l|l|l|l|l|}
\hline Sample & & $\begin{array}{l}\mathbf{R}_{\mathbf{m}}\left(\mathbf{m L} \mathbf{k g}^{-1}\right. \\
\left.\mathbf{h}^{-\mathbf{1}}\right)\end{array}$ & $\begin{array}{l}\mathbf{K}_{\mathbf{m}} \mathbf{( \%} \\
\left.\mathbf{O}_{\mathbf{2}}\right)\end{array}$ & $\begin{array}{l}\mathbf{K}_{\mathbf{i}} \mathbf{( \%} \\
\left.\mathbf{C O}_{\mathbf{2}}\right)\end{array}$ & $\mathbf{r}^{\mathbf{2}}$ \\
\hline \multirow{2}{*}{ Treated pear } & $\mathrm{O}_{2}$ & 64.77 & 55.6448 & 0.7295 & 0.989 \\
\hline \multirow{2}{*}{ Untreated pear } & $\mathrm{CO}_{2}$ & 42.15 & 46.0486 & 1.1344 & 0.992 \\
\hline & $\mathrm{O}_{2}$ & 35.62 & 16.1176 & 1.6461 & 0.990 \\
\hline & $\mathrm{CO}_{2}$ & 34.40 & 50.7237 & 2.7996 & 0.996 \\
\hline
\end{tabular}

Fig.1 Changes in O2and CO2concentration with storage time inside respirometer

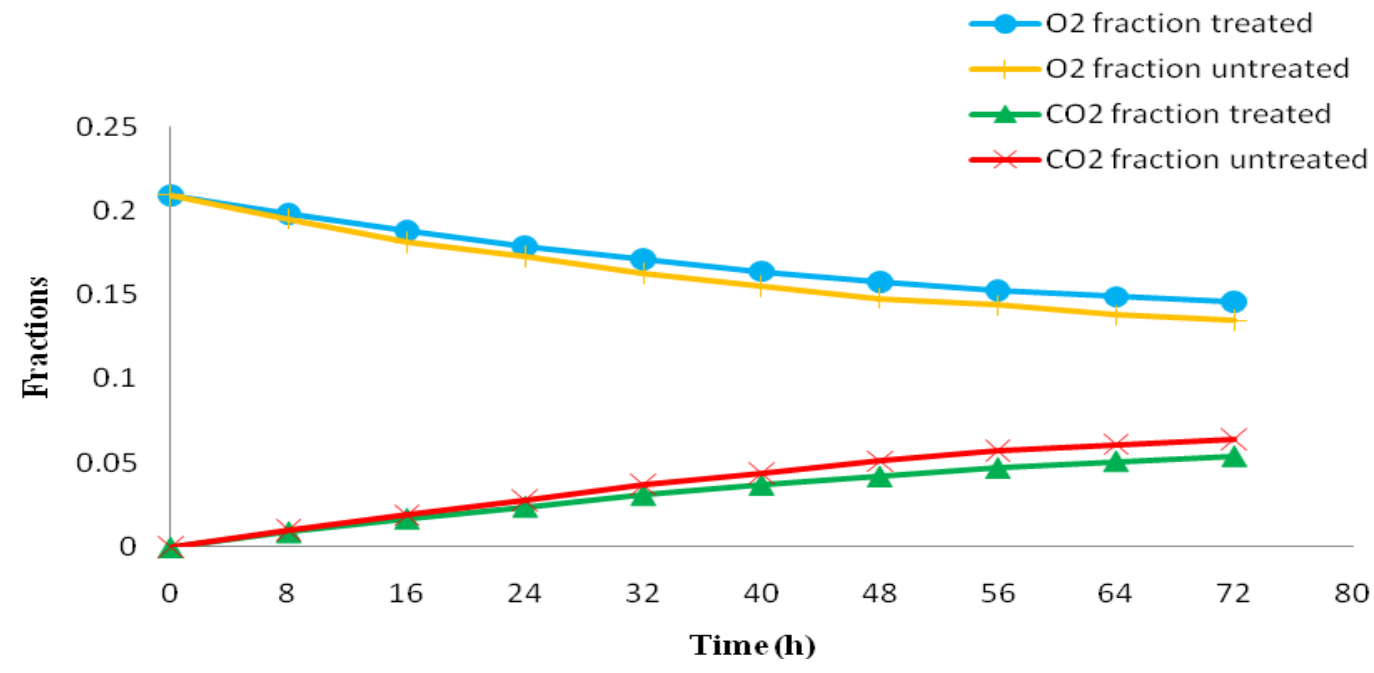


Fig.2 Experimentally estimated and predicted respiration rates for treated pear

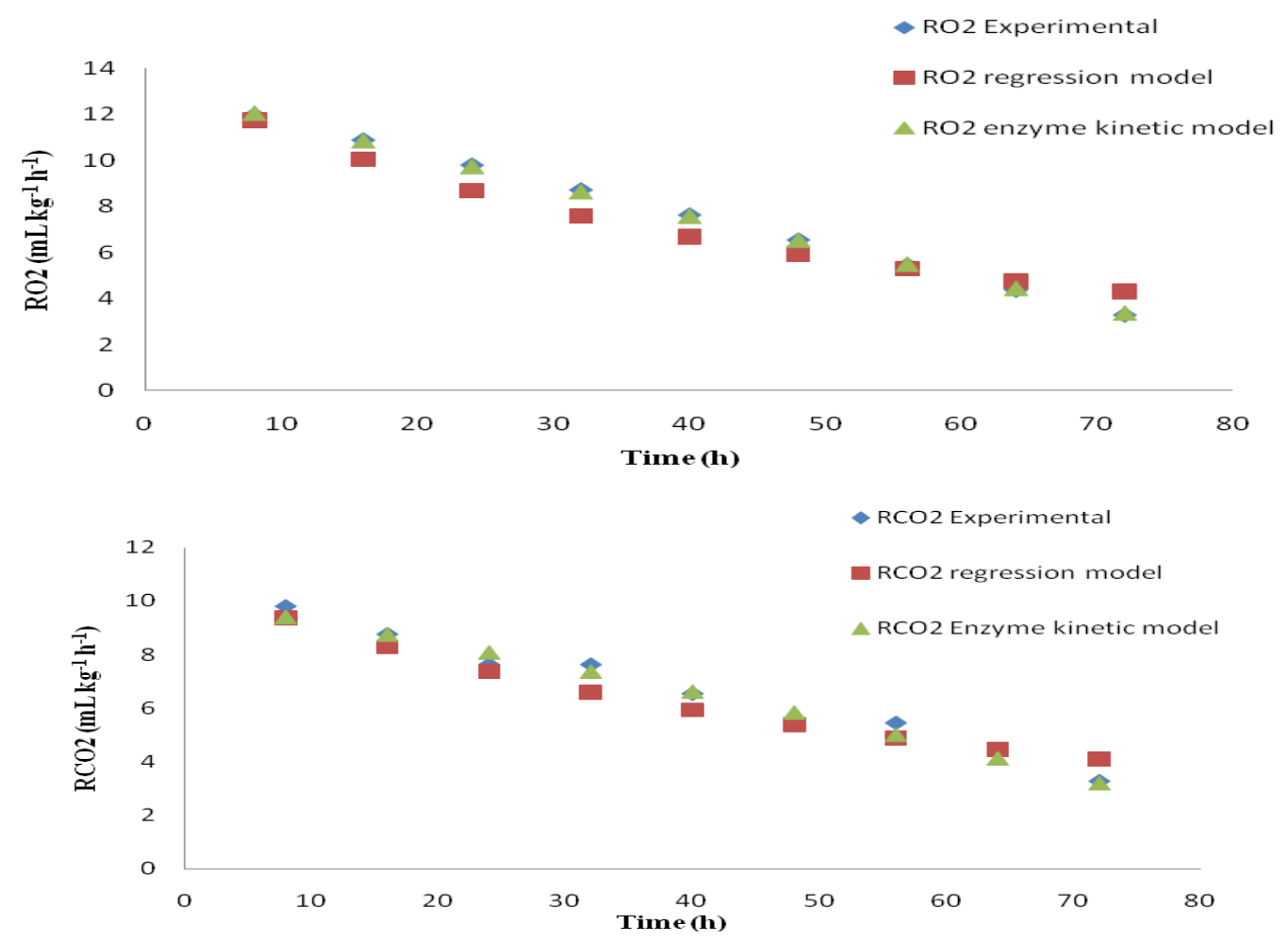

Fig.3 Experimentally estimated and predicted respiration rates for untreated pear

Fig.4 Change in gaseous composition inside the package for treated cut-pear

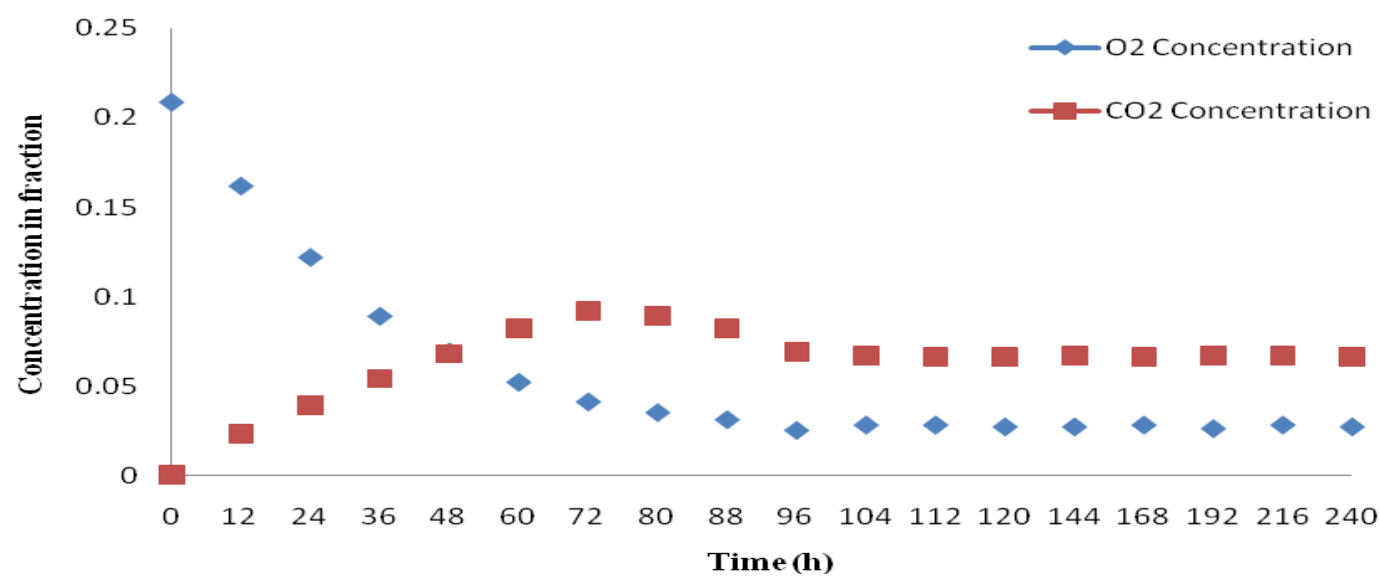

Fig.5 Change in gaseous composition inside the package for untreated cut-pear

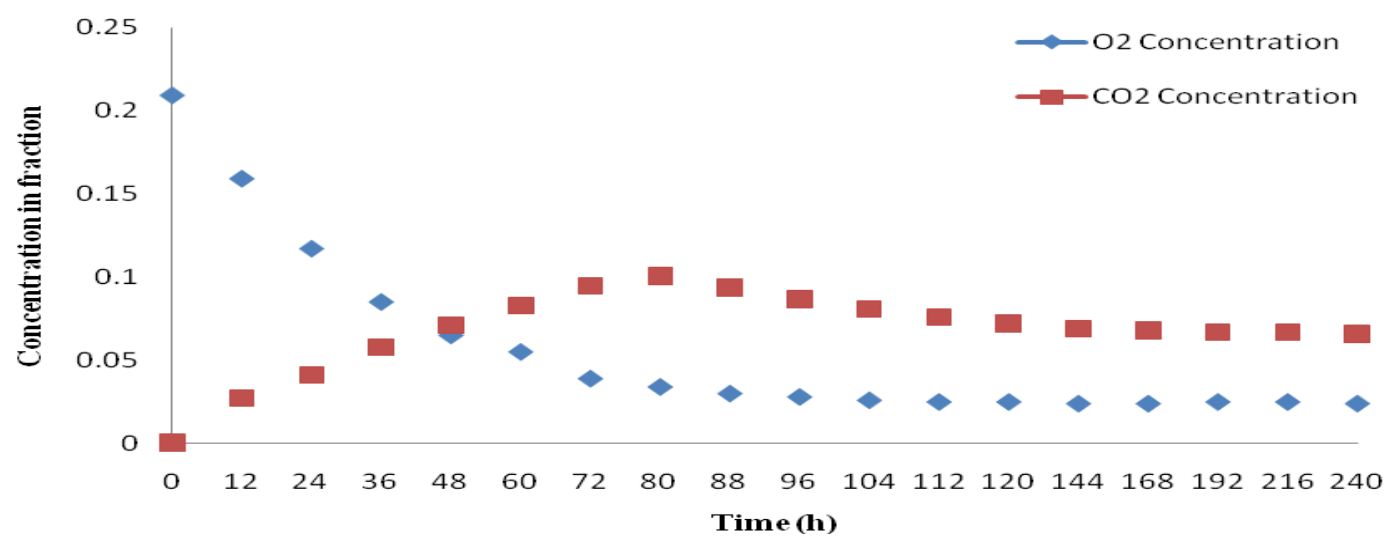

Plate.1 Measurement of respiration data for Fresh-cut pears

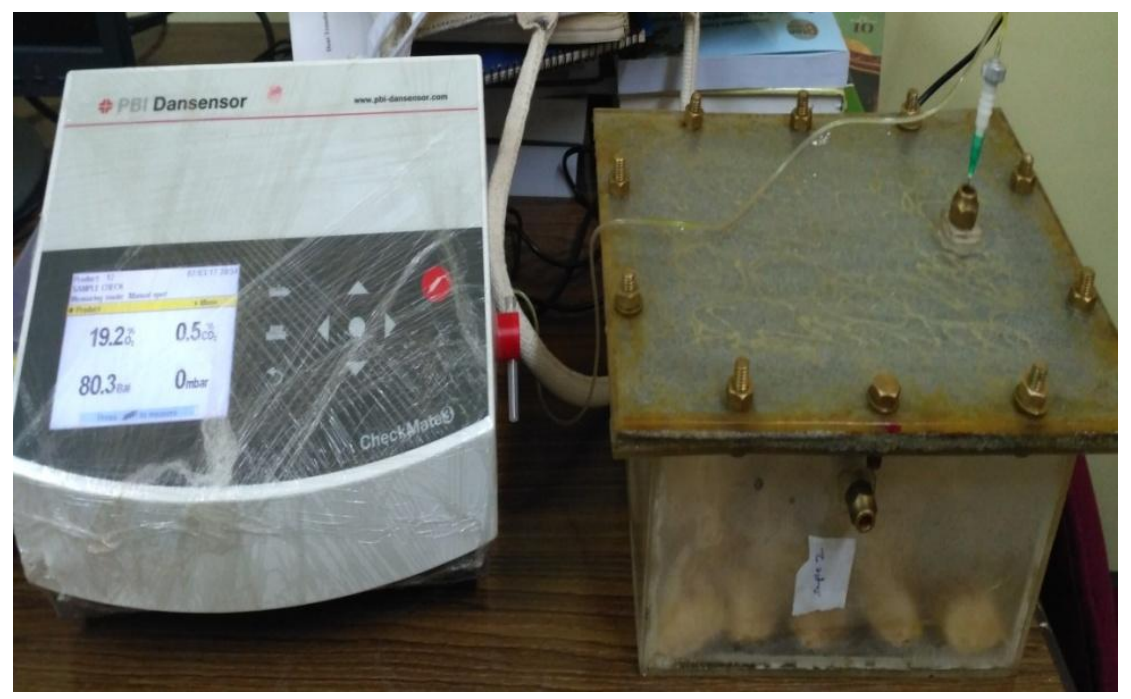


The experimental and predicted respiration rates for treated and untreated fresh-cut pear at different time intervals are shown in Figure 2 and 3, respectively. The mean relative deviation moduli between predicted and those of experimentally determined respiration rates for treated were found to be $9.35 \%$ and 6.96 $\%$ for $\mathrm{O} 2$ consumption and $\mathrm{CO} 2$ evolution for untreated $8.77 \%$ and $9.53 \%$ for $\mathrm{O} 2$ consumption and $\mathrm{CO} 2$ evolution respectively. This suggests that the respiration rates predicted by the regression model are in reasonably good agreement with experimentally determined respiration rates for cut-pear.

\section{Prediction of respiration rates based on enzyme kinetics model}

Multiple linear regression analysis was done to obtain the parameters of enzyme kinetics model such as $\mathrm{R}_{\mathrm{m}}, \mathrm{K}_{\mathrm{m}}, \mathrm{K}_{\mathrm{i}}$. In equations (10) and (11), dependent variables such as the rate of respiration $\left(\mathrm{R}_{\mathrm{y}}\right)$ or $\left(\mathrm{R}_{\mathrm{z}}\right)$ were obtained from equations (8) and (9), respectively. The independent variables such as $\mathrm{O}_{2}$ concentration (y) and $\mathrm{CO}_{2}$ concentration (z) were obtained through experiments as shown in Figure 1. The model parameters of the uncompetitive inhibition enzyme kinetics as shown in equations (10) and (11) were calculated from the coefficients of multiple linear regression analysis. The model parameters and coefficients of determination $\left(\mathrm{r}^{2}\right)$ for both the sample is shown in Table 3. By using the model parameters and equations (3) and (4), respiration rates for both the sample predicted for different combinations of $\mathrm{O}_{2}$ and $\mathrm{CO}_{2}$ concentrations as shown in Figure 2 and 3 . The mean relative deviation moduli between predicted and those of experimentally determined respiration rates were found to be $3.31 \%$ and $6.68 \%$ for $\mathrm{O}_{2}$ consumption and $\mathrm{CO}_{2}$ evolution respectively. This suggests that the respiration rates predicted by the enzyme-kinetic model at different time intervals were fairly good agreement with experimental respiration rates.

\section{Effect of modified Atmospheric packaging on chemically treated and untreated cut- pear}

Headspace $\mathrm{O}_{2}$ and $\mathrm{CO}_{2}$ compositions of both the samples were measured. The level of $\mathrm{O}_{2}$ and $\mathrm{CO}_{2}$ concentration maintained by respiration of commodity and permeability of packaging film is shown in Figure 4 for treated pear and Figure 5 for untreated pear. Under all the packaging treatments, initially, a rapid decrease in $\mathrm{O}_{2}$ and a corresponding increase in $\mathrm{CO}_{2}$ concentrations were observed on the first day to the fifth day, which may be attributed to the initial adjustment and high respiratory behaviour of fruits in the transient state of equilibrium as well as the permeability of the packaging film. For both the samples equilibrium of gases established on fifth days of storage. The maximum decrease in $\mathrm{O}_{2}$ was $2.5 \%$ in $96 \mathrm{~h}$ then slightly increased and maintained equilibrium to 2.7\% in 112 h. For $\mathrm{CO}_{2}$, maximum concentration increase was $8.9 \%$ in $80 \mathrm{~h}$ and then decreased and maintained equilibrium to6.6\% in $112 \mathrm{~h}$ depends on permeability. Similarly, for untreated pear sample, the maximum decrease in $\mathrm{O}_{2}$ was observed to be $3.4 \%$ in 144 hand maintained equilibrium to $2.4 \%$ in 144 hand for $\mathrm{CO}_{2}$ maximum decreases to $10.1 \%$ in $80 \mathrm{~h}$ and then decreased and maintained equilibrium to $6.8 \%$ in $144 \mathrm{~h}$ throughout the storage period.

In conclusion, the respiration rates were found to decrease with storage time. The respiration rate of fresh-cut pear was well described by a Michaelis-Menten model. The effect of $\mathrm{O}_{2}$ and $\mathrm{CO}_{2}$ concentration on respiration rate was found to fit well with the uncompetitive inhibition enzyme kinetics for both the sample. The mean relative deviation moduli between predicted and those of 
experimentally determined respiration rates for treated were found to be $9.35 \%$ and 6.96 $\%$ for $\mathrm{O}_{2}$ consumption and $\mathrm{CO}_{2}$ evolution for untreated $8.77 \%$ and $9.53 \%$ for $\mathrm{O}_{2}$ consumption and $\mathrm{CO}_{2}$ evolution respectively. Based on the results of the investigation it maybe concluded that polypropylene film can be used to maintain the proper gaseous composition inside modified atmospheric packaging for both freshly cut-pear chemically treated and untreated pear.The model can successfully be used to develop a modified atmosphere package.

\section{References}

Aguayo, E., Jansasithorn, R., and Kader, A. A. (2006). Combined effects of 1methylcyclopropene, calcium chloride dip, and/or atmospheric modification on quality changes in fresh-cut strawberries. Postharvest Biology and Technology, 40 269-278.

Alandes, L., Hernando, I., Quiles, A., PerezMunuera, I., and Lluch, M. A. (2006). Cell wall stability of fresh-cut Fuji apples treated with calcium lactate. Journal of Food Science, 71(9), 615620.

Amiot, M. J., Tacchini, M., Aubert, S. Y., and Oleszek, W. (1995). Influence of cultivar, maturity stage, and storage conditions on phenolic composition and enzymatic browning in pear fruits. Journal of Agricultural and Food Chemistry, 43, 1132-1137.

Arias, E., Gonzalez, J., Lopez-Buesa, P., and Oria, R. (2008). Optimization of processing of fresh-cut pear. Journal of the Science of Food and Agriculture, 88(10), 1755-1763.

Das, E., Gurakan, G. C., and Bayindirli, A. (2006). Effect of controlled atmosphere storage, modified atmosphere packaging and gaseous ozone treatment on the survival of Salmonella Enteritidis on cherry tomatoes. Food Microbiology, 23, 430-438.

Dong, X., Wrolstad, R. E., and Sugar, D. (2000). Extending the shelf life of freshcut pears. Journal of Food Science, 65(1), 181-186.

Forcier, F., Raghavan, G.S.V., Gariepy, Y.(1987). Electronic sensor for the determination of fruit and vegetable respiration. International Journal of Refrigeration, 10, 353-356.

Gorny, J. R., Hess-Pierce, B., Cifuentes, R. A., and Kader, A. A. (2002). Quality changes in fresh-cut pear slices as affected by controlled atmospheres and chemical preservatives. Postharvest Biology and Technology, 24(3), 271278.

Hagger, P.E., Lee, D. S., Yam, K. L. (1992). Application of an Enzyme Kinetics Based Respiration Model to Closed System Experiments for Fresh Produce. Journal of Food Process Engineering, $15,143-157$

Halachmy, I.B., and C.H. Mannheim. (1991). Modified Atmosphere Packaging of Fresh Mushrooms. Packaging Technology and Science, 4(5), 279-286.

Kang, J. S., and Lee, S. (1998). A kinetic model for transpiration of fresh produce in a controlled atmosphere. Journal of Food Engineering, 35, 65-73.

Kays, S. J. (1991). Metabolic Processes in Harvested Products Respiration. In Post Harvest Physiology of Perishable Plant Products, Kay, S. J. (Ed.), Van Nostrand Reinhold Publication, New York, 75-79.

Lee, D. S., Haggar, P. E., Lee, J., and Yam, K. L. (1991). Model for fresh produce respiration in modified atmospheres based on principles of enzyme kinetics. Journal of Food Science, 56(6), 15801585.

Mahajan, P. V. (2001). Studies on Control atmosphere storage for apple and litchi 
using liquid nitrogen. $\mathrm{PhD}$ Thesis, Department of Agriculture and Food Engineering, Indian Institute of Technology, Kharagpur, India.

Mangaraj, S., Goswami, T. K., Giri, S. K., and Joshy, C. G. (2014). Design and development of a modified atmosphere packaging system for guava (cv. Baruipur). Journal of Food Science and Technology, 5(11), 2925-2946.

Mangaraj, S., andGoswami, T. K. (2011). Measurement and modelling of the respiration rate of guava (cv. Baruipur) for modified atmosphere packaging. International Journal of Food Properties, 14(3), 609-628.

McLaughlin, C. P., and O'Beirne, D. (1999). Respiration rate of a dry coleslaw mix as affected by storage temperature and respiratory gas concentrations. Journal of Food Science, 64, 116-119.

Nath, A., Deka, B. C., Singh, A., Patel, R.K., Paul, D., Misra, L.K., and Ojha, H. (2012). Extension of the shelf life of pear fruits using different packaging materials. Journal of Food Science and Technology,49(5), 556-563.

Oms-Oliu, G., Aguilo-Aguayo, I., and MartinBelloso, O. (2006). Inhibition of browning on fresh-cut pear wedges by natural compounds. Journal of Food Science, 71(3), 216-224.

Parle, M., and Arzoo. (2016). Why is pear so dear. International Journal of Research in Ayurveda and Pharmacy, 7(1), 108113.

Rocculi, P., Romani, S., and Rosa, M. D. (2004). Evaluation of physicochemical parameters of minimally processed apples packed in non-conventional modified atmosphere. Food Research International,37(4), 329-335.

Reiland, H., and Slavin, J. (2015). Systematic Review of Pears and Health. Nutrition Today,50(6), 301-305.

Sapers, G.M., andMiller, R. L. (1998). Browning inhibition in fresh-cut pears.Journal of Food Science, 63(2), 342-346.

Sivakumar, D., and Korsten, L. (2006). Influence of modified atmosphere packaging and postharvest treatments on quality retention of litchi cv. Mauritius. Postharvest Biology and Technology, 41(2), 135-142.

Soliva-Fortuny, R.C., Biosca-Biosca, M., Grigelmo-Miguel, N., and MartinBelloso, O.(2002) Browning, polyphenol oxidase activity and headspace gas composition during storage of minimally processed pears using modified atmosphere packaging. Journal of the Science of Food and Agriculture, 82(13), 1490-1496.

Velmurugan, C., and Bhargava, A. (2013). Anti-Diabetic and hypolipidemic activity of fruit of Pyrus communis L. in hyperglycaemic rats. Asian Journal of Pharmaceutical and Clinical Research, 6, 108-111.

Vilas-Boas, E. V. de B., and Kader, A. A. (2006). Effect of atmospheric modification, 1-MCP and chemicals on quality of fresh-cut banana. Postharvest Biology and Technology, 39, 155-162.

\section{How to cite this article:}

Ram Prakash Kumar and Goswami, T.K. 2019. Modelling the Respiration Rate of Fresh-Cut Pear (Pyrus communis L.) Packaged in Modified Atmosphere. Int.J.Curr.Microbiol.App.Sci. 8(04): 574-584. doi: https://doi.org/10.20546/ijcmas.2019.804.062 